\title{
Survei Kemampuan Kondisi Fisik Peserta Kegiatan Ekstrakurikuler Bolabasket Sekolah Menengah Atas
}

\author{
Rista Dole*, Siti Nurrochmah \\ Universitas Negeri Malang, Jl. Semarang No. 5 Malang, Jawa Timur, Indonesia \\ *Penulis korespondensi, Surel: dolerista@gmail.com
}

Paper received: 3-5-2021; revised: 24-5-2021; accepted: 28-5-2021

\begin{abstract}
Abstrak
Tujuan penelitian ini untuk mengetahui dan mengkaji keadaan kemampuan kondisi fisik peserta kegiatan ekstrakurikuler bolabasket SMAN 1 Gondanglegi Kabupaten Malang. Penelitian ini menggunakan rancangan survei bentuk deskriptif kuantitatif. Subjek penelitian ini berjumlah 30 peserta kegiatan ekstrakurikuler bolabasket SMAN 1 Gondanglegi Kabupaten Malang. Pengumpulan data menggunakan teknik pengukuran bentuk tes yaitu tes kemampuan kondisi fisik berupa tes kecepatan, kelincahan, dan daya ledak (otot lengan dan tungkai). Hasil analisis data pada kegiatan ekstrakurikuler bolabasket SMAN 1 Gondanglegi Kabupaten Malang tes kecepatan untuk putra 53,3 persen termasuk kategori "sedang", sedangkan untuk putri 36,7 persen kategori "sedang". Tes kelincahan untuk putra 33,3 persen pada kategori "sedang", sedang untuk putri 73,3 persen kategori "sedang". Tes daya ledak otot lengan untuk putra 53,3 persen kategori "sedang", sedangkan untuk putri 33,3 persen kategori "sedang". Tes daya ledak otot tungkai untuk putra 33,3 persen termasuk kategori "sedang", sedangkan untuk putri 40 persen kategori "baik". Hasil penelitian disimpulkan bahwa pada peserta kegiatan ekstrakurikuler bolabasket SMAN 1 Gondanglegi Kabupaten Malang lebih dominan pada kategori "sedang".
\end{abstract}

Kata kunci: kondisi fisik; ekstrakurikuler; bolabasket

\section{Pendahuluan}

Bolabasket adalah salah satu olahraga paling popular didunia, penggemarnya yang berasal dari segala usia merasakan bahwa bolabasket adalah olahraga menyenangkan, kompettitif, mendidik, menghibur, dan menyehatkan. Keterampilan-keterampilan perseorangan seperti tembakan, umpanan, dribble, lay up maupun rebound, serta kerja sama tim untuk menyerang ataupun bertahan merupakan syarat agar berhasil dalam memainkan olahraga ini. Roji \& Yulianti (2014) berpendapat bahwa permainan bolabasket adalah permainan olahraga yang beregu terdiri atas dua tim beranggota lima orang dan saling bertanding untuk mencetak poin dengan memasukkan bola ke dalam keranjang lawan.

Permainan bolabasket adalah salah satu cabang olahraga yang sering diselenggarakan di hampir setiap sekolah yang menyelenggarakan kegiatan ekstrakurikuler. Peserta kegiatan ekstrakurikuler tidak hanya dikenalkan permainan bolabasket saja. Namun akan diberikan materi-materi secara detail yang berkaitan dengan bola basket, mulai dari peraturan permainan bolabasket, teknik dasar, strategi bermain, serta kondisi fisik.

Kondisi fisik adalah satu kesatuan utuh dari komponen-komponen yang tidak dapat dipisahkan begitu saja, baik peningkatan maupun pemeliharaannya. Artinya seluruh komponen kondisi fisik harus dikembangkan (Amiq 2016). Secara umum kondisi fisik yang diperlukan dalam masing-masing olahraga adalah sama, artinya setiap cabang olahraga memerlukan kondisi fisik dalam usaha mencapai prestasi yang optimal, begitu halnya dalam olahraga basket. Seorang dinyatakan dalam keadaan kondisi fisik yang baik kalau ia mampu 
melakukan aktivitasnya tanpa kelelahan yang berlebihan. Kondisi fisik yang lebih baik banyak memperoleh keuntungan diantaranya mampu dan mudah mempelajari keterampilan baru yang relatif sulit, tidak mudah lelah dalam mengikuti latihan dan pertandingan dengan lebih baik, program latihan dapat diselesaikan tanpa banyak kendala, waktu pemulihan lebih cepat dan dapat menyelesaikan latihan-latihan yang relatif berat.

Dalam olahraga bolabasket komponen kondisi fisik yang banyak dibutuhkan meliputi komponen kekuatan, kelentukan, komposisi tubuh, daya tahan, kecepatan, kelincahan, keseimbangan, koordinasi, dan kecepatan reaksi. Diantara komponen tersebut kecepatan gerak, kelincahan dan daya ledak (otot lengan dan otot tungkai) sangat dibutuhkan dan sebagai kunci penentu kinerja olahragawan. Kecepatan gerak adalah kemampuan untuk menempuh jarak tertentu dalam waktu sesingkat-singkatnya (Wiarto 2013), sedangkan menurut (Abduljabar \& Lubay 2015) kelincahan adalah kemampuan untuk mengubah arah dan posisi tubuh dengan cepat dan tepat dalam waktu sedang bergerak, tanpa kehilangan keseimbangan, serta (Sumaryoto \& Nopembri 2017:155) berpendapat bahwa daya ledak adalah kemampuan seseorang dalam mengeluarkan tenaga sebanyak-banyaknya dalam waktu yang sangat singkat, jadi daya ledak merupakan perpaduan antara kecepatan dan kekuatan yang dimiliki seseorang. Untuk mengetahui kondisi fisik unsur tersebut penting dilakukan tes dan pengukuran pada masing-masing unsur tersebut pada kenyataannya.

Di Sekolah SMAN 1 Gondanglegi Kabupaten Malang menyajikan mata kegiatan ekstrakurikuler khusus bidang olahraga mencangkup bolavoli, sepak bola, futsal dan bolabasket. Diantara olahraga mata kegiatan olahraga tersebut, mata kegiatan bolabasket merupakan jenis kegiatan yang banyak digemari putra maupun putri. Untuk menghadapi berbagai event pihak sekolah mempersiapkan kondisi fisik setiap peserta ekstrakurikuler. Melalui pelaksanaan penyelenggaraan ekstrakurikuler pada cabang olahraga yang dipersiapkan untuk event seperti POPDA tingkat daerah. Berdasarkan observasi di lokasi pelatih tidak pernah melakukan pengukuran bentuk tes untuk mengetahui keadaan dan perkembangan unsur-unsur kondisi fisik yang dibutuhkan dalam permainan bolabasket, sedangkan hasil dari pengamatan telah ditemukan sebagian besar peserta kegiatan ekstrakurikuler pada waktu latihan yaitu saat bermain, tidak dapat bermain dengan maksimal karena kondisi fisik yang dimiliki belum menunjukkan kondisi yang baik. Misalnya gerak kondisi fisik bentuk kelincahan umumnya peserta kegiatan ekstrakurikuler kurang lincah, kemampuan gerakan passing tidak juga menunjukkan kecepatan dan ketepatan pada sasaran atau teman bermain, dan lain-lain. Maka dari itu peserta yang mengikuti kegiatan ekstrakurikuler bolabasket, kondisi fisik peserta tergolong rendah.

Wiarto (2014) berpendapat bahwa olahraga adalah kegiatan fisik, adanya aktivitas fisik yang dicirikan gerak tubuh dengan pola tertentu, dilakukan secara berkesinambungan, teratur, untuk mencapai tujuan olahraga tersebut. Melalui olahraga manusia dapat melakukan interaksi dimana terjadinya atau adanya kontak sosial dan terjadinya komunikasi. Sedangkan menurut Purwadi (2014) olahraga adalah aktivitas jasmani atau fisik yang berbentuk perlombaan atau pertandingan dengan tujuan untuk memperoleh prestasi yang tinggi, kemenangan dan rekreasi.

Bolabasket adalah permainan yang dimainkan oleh dua regu yang masing-masing regu terdiri dari lima orang pemain. Permainan bolabasket bertujuan untuk mencari nilai atau angka sebanyak-banyaknya dengan memasukkan bola ke keranjang lawan dengan waktu yang 
telah ditentukan (Muhajir 2014). Ambler (2016) berpendapat dalam bolabasket terdapat dasar-dasar permainan yakni satu lawan atau dua lawan dua, dimana lima pemain ikut terlibat dalam permainan ini. Strategi penyerangan ialah membuka jalan untuk seorang penembak melakukan suatu tembakan yang baik dan sebaliknya untuk tim yang bertahan, harus berjuang untuk menghindari terjadinya tembakan.

Kondisi fisik memegang peranan yang sangat penting dalam mempertahankan atau meningkatkan derajat kesegaran jasmani, derajat kesegaran jasmani seseorang sangat menentukan kemampuan fisiknya dalam melaksanakan aktivitas sehari-hari. Selain berguna untuk meningkatkan kesegaran jasmani, kondisi fisik juga bisa dikatakan sebagai program pokok dalam pembinaan seorang atlet untuk berprestasi dalam cabang olahraga tersebut (Giriwijoyo, dkk 2005). Rahayu (2017) berpendapat bahwa kondisi fisik kebutuhan suatu aktivitas ke dalam suatu kerja gerak dalam keolahragaan yang berkenaan dengan komponenkomponen fisik sebagai penunjang dalam cabang olahraga tertentu, seperti: kekuatan, daya tahan, kecepatan, daya ledak, kelentukan, kelincahan, ketepatan, keseimbangan, koordinasi. Dalam melakukan suatu aktivitas jasmani yang termasuk dalam kegiatan keolahragaan tertentu memerlukan suatu kemampuan fisik yang baik.

Kecepatan gerak adalah kemampuan seseorang berpindah dari satu tempat ke tempat yang lain dengan waktu yang cepat (Wiradihardja \& Syarifudin 2017). Menurut Nurrocmah (2016) kecepatan gerak adalah kemampuan seseorang untuk berpindah tempat/bergerak pada seluruh tubuh atau bagian dari satu tempat ke tempat lain dalam waktu yang singkat atau cepat. Berdasarkan pernyataan dari beberapa ahli, maka dapat disimpulkan bahwa kecepatan gerak adalah kemampuan seseorang dalam menggerakkan tubuhnya dalam waktu yang sangat singkat atau cepat.

Kelincahan (agility) adalah kemampuan seseorang untuk dapat mengubah arah dengan cepat, singkat dan tepat pada waktu bergerak tanpa kehilangan keseimbangan (Sumaryoto \& Nopembri 2014). Sedangkan menurut Sidik, Pesurnay \& Afari (2019) agility atau kelincahan adalah kemampuan gerak maksimal seseorang dalam mengubah posisinya atau arah tubuhnya dengan cepat, tepat dan tanpa kehilangan keseimbangan tubuhnya. Dan gerakan tersebut harus dikoordinasi dengan baik. Berdasarkan beberapa pernyataan di atas, maka dapat ditarik kesimpulan bahwa kelincahan adalah kemampuan seseorang dalam mengubah posisi tubuhnya atau mengubah arah dalam waktu yang sangat singkat atau cepat tanpa kehilangan keseimbangan yang dilakukan secara bersama-sama dengan gerakan yang lain

Daya ledak adalah kemampuan otot untuk mengerahkan kekuatan maksimal dalam waktu yang sangat cepat/singkat (Yudiana, dkk 2012). Abduljabar \& Lubay (2015) berpendapat bahwa daya ledak adalah kemampuan otot atau sekelompok otot seseorang kekuatan maksimal yang dikerahkan dalam waktu yang sesingkat-singkatnya. Menurut (Amiq 2015) daya ledak adalah kemampuan seseorang untuk mempergunakan kekuatan maksimum yang dikeluarkan dalam waktu yang sependek-pendeknya. Dalam hal ini, dapat dinyatakan bahwa daya ledak (power) sama dengan kekuatan (force) x kecepatan (felocity). Dari beberapa pernyataan diatas, maka disimpulkan bahwa daya ledak adalah kemampuan otot yang mengerahkan kekuatan dengan waktu yang sesingkat-singkatnya.

Kegiatan ekstrakurikuler merupakan suatu kegiatan yang memfasilitasi pengembangan diri siswa dan dapat dilaksanakan diluar jam sekolah maupun pada jam kegiatan belajar mengajar di dalam kelas (Sopiatin 2010). Sedangkan menurut Kompri (2015) kegiatan 
ekstrakurikuler merupakan kegiatan yang dilakukan di luar kelas atau di luar jam pelajaran untuk membuhkembangkan potensi bakat dan minat peserta didik menjadi lebih baik.

Berdasarkan pernyataan di atas dari beberapa ahli, maka dapat disimpulkan bahwa kegiatan ekstrakurikuler adalah kegiatan yang dilakukan di luar jam pelajaran yang bertujuan untuk mengembangkan setiap bakat, minat, serta potensi peserta didik dan memberikan kesempatan peserta didik untuk berkreasi dengan setiap kemampuan yang dimilikinya. Selain itu kegiatan ekstrakurikuler juga dapat meningkatkan kemampuan kognitif, afektif dan psikomotorik peserta didik dan pelaksanaan ekstrakurikuler dibina oleh setiap petugas khusus sesuai dengan bidangnya yang telah ditentukan oleh pihak sekolah.

\section{Metode}

Rancangan penelitian ini menggunakan rancangan survei. Ditinjau dari tujuan penelitian maka penelitian ini termasuk jenis penelitian deskriptif. Subjek penelitian ini adalah peserta kegiatan ekstrakurikuler bolabasket SMAN 1 Gondanglegi Kabupaten Malang yang berjumlah 30 orang. Instrumen penelitian yang digunakan pada penelitian ini berupa instrumen tes dan non tes. Tes yang digunakan berupa tes, kecepatan gerak, kelincahan dan daya ledak (otot lengan dan otot tungkai). Sedangkan instrumen non-tes berupa observasi yang digunakan untuk mengamati pelaksanaan tiap-tiap tes. Teknik pengumpulan data yang digunakan pada penelitian ini berupa teknik pengukuran bentuk tes dan pengukuran. Bentuk tes yang diberikan berupa tes kemampuan kondisi fisik yang meliputi tes kecepatan gerak, kelincahan dan daya ledak (otot lengan dan otot tungkai). Teknik pengumpulan data yang digunakan pada penelitian ini berupa teknik pengukuran bentuk tes dan pengukuran. Bentuk tes yang diberikan berupa tes kemampuan kondisi fisik yang meliputi tes kecepatan gerak, kelincahan dan daya ledak (otot lengan dan otot tungkai). Teknik analisis statistika deskriptif kuantitatif yang digunakan berupa modus, mean, variasi populasi, standar deviasi, dan koefisien variansi.

\section{Hasil dan Pembahasan}

\subsection{Hasil}

Dalam penelitian ini data yang diperoleh setelah disajikan melalui deskripsi data, selanjutnya data dianalisis dengan menggunakan statistika deskriptif bentuk variabilita/penyebaran. Berikut ini disajikan menggunakan teknik standar deviasi, varian dan koefisien variansi. Berikut ini akan disajikan hasil analisis data.

Tabel 1. Penyajian Hasil Analisis Data Tes Lari 30 Meter, T-Test, Tes Chest Pass Throw, dan Tes Vertical Jump untuk Peserta Kegiatan Ekstrakurikuler Bolabasket SMAN 1 Gondanglegi Kabupaten Malang Kelompok Putra

\begin{tabular}{|c|c|c|c|c|c|}
\hline \multirow{2}{*}{ No } & \multirow{2}{*}{ Jenis Tes } & \multicolumn{4}{|c|}{ Ukuran Statistik } \\
\hline & & Mean & SD & Varian & KV (\%) \\
\hline 1. & Lari 30 Meter & 4,66 detik & 0,2714 detik & 0,074 detik & 5,82 \\
\hline 2. & T-Test & 11,78 detik & 0,5176 detik & 0,268 detik & 4,40 \\
\hline 3. & $\begin{array}{l}\text { Tes Chest Pass } \\
\text { throw }\end{array}$ & 3,76 meter & 0,4650 meter & 0,216 meter & 12,37 \\
\hline 4. & Tes Vertical Jump & $274,73 \mathrm{~cm}$ & $9,3920 \mathrm{~cm}$ & $88,210 \mathrm{~cm}$ & 3,42 \\
\hline
\end{tabular}


Berdasarkan sajian hasil analisis pada data tes lari 30 meter, $t$ - test, tes chest pass throw, dan tes vertical jump untuk peserta kegiatan ekstrakurikuler Bolabasket SMAN 1 Gondanglegi Kabupaten Malang kelompok putra yang berjumlah 15 peserta maka diperoleh hasil tes lari 30 meter dengan hasil nilai mean 4,66 detik, nilai SD 0,2714 detik, varian 0,074 detik dan KV 5,82\%. Sedangkan T-test memperoleh mean 11,78 detik, nilai SD 0,5176, varian 0,268 detik, KV 4,40\%. Untuk tes chest pass throw mean 3,76 meter, nilai SD 0,4650 meter, varian 0,216 meter, KV 12,37\%. Dan untuk tes vertical Jump memperoleh mean 274,73 cm, nilai SD 9,3920 $\mathrm{cm}$, varian $88,210 \mathrm{~cm}$, dan KV 3,42\%.

Tabel 2. Penyajian Hasil Analisis Data Tes Lari 30 Meter, T-Test, Tes Chest Pass Throw, dan Tes Vertical Jump untuk Peserta Kegiatan Ekstrakurikuler Bolabasket SMAN 1 Gondanglegi Kabupaten Malang Kelompok Putri

\begin{tabular}{llcccc}
\hline & & \multicolumn{4}{c}{ Ukuran Statistik } \\
\cline { 3 - 6 } No & Jenis Tes & Mean & SD & Varian & KV \\
\cline { 3 - 6 } & & 5,68 detik & 0,6154 detik & 0,379 detik & 10,84 \\
1. & Lari 30 Meter & 13,22 detik & 1,3673 detik & 1,870 detik & 10,35 \\
2. & T- Test & 3,44 meter & 0,4288 meter & 0,184 meter & 12,47 \\
3. & Tes Chest Pass & & & \\
& throw & & & \\
4. & Tes Vertical & $245,87 \mathrm{~cm}$ & $9,8841 \mathrm{~cm}$ & $97,695 \mathrm{~cm}$ & 4,02 \\
& Jump & & & & \\
\hline
\end{tabular}

Berdasarkan sajian hasil analisis pada data tes lari 30 meter, $t$ - test, tes chest pass throw, dan tes vertical jump untuk peserta kegiatan ekstrakurikuler Bolabasket SMAN 1 Gondanglegi Kabupaten Malang kelompok putra yang berjumlah 15 peserta maka diperoleh hasil tes lari 30 meter dengan hasil nilai mean 5,68 detik, nilai SD 0,6154 detik, varian 0,379 detik dan KV 10,84\%. Sedangkan $T$ - test memperoleh mean 13,22 detik, nilai SD 1,3673, varian 1,870 detik, KV 10,35\%. Untuk tes chest pass throw mean 3,44 meter, nilai SD 0,4288 meter, varian 0,184 meter, KV 12,47\%. Dan untuk tes vertical Jump memperoleh mean 245,87 cm, nilai SD 9,8841 cm, varian 97,695 cm, dan KV 4,02\%.

\subsubsection{Hasil Tes Lari 30 Meter}

Tujuan tes ini adalah untuk mengetahui kemampuan kecepatan bergerak seseorang dalam berlari.

Tabel 3. Klasifikasi Hasil Unsur Kecepatan Tes Lari 30 Meter pada Peserta Kegiatan Ekstrakurikuler Bolabasket SMAN 1 Gondanglegi Kabupaten Malang Kelompok Putra

\begin{tabular}{ccccc}
\hline Skor Interval & Frekuensi & $\begin{array}{c}\text { Frekuensi Relatif } \\
\text { (\%) }\end{array}$ & Kriteria & $\begin{array}{c}\text { Jumlah } \\
\text { Kriteria }\end{array}$ \\
\hline$\leq 4,25$ & 0 & 0 & Baik Sekali & 3 \\
$4,25-4,52$ & 3 & 20 & Baik & \\
\hline $4,52-4,79$ & 6 & 40 & Sedang & \\
$4,79-5,06$ & 5 & 33,3 & Kurang & 12 \\
$\geq 5,06$ & 1 & 6,7 & Kurang & \\
& & & Sekali & \\
\hline
\end{tabular}


Dengan demikian berdasarkan hasil analisis pada tabel 4 keseluruhan 12 orang (80\%) dari 15 orang hasil tes cenderung banyak berada di bawah rata-rata (dibawah kriteria baik).

Tabel 4. Klasifikasi Hasil Unsur Kecepatan Tes Lari 30 Meter pada Peserta Kegiatan Ekstrakurikuler Bolabasket SMAN 1 Gondanglegi Kabupaten Malang Kelompok Putri

\begin{tabular}{ccccc}
\hline Skor Interval & Frekuensi & $\begin{array}{c}\text { Frekuensi Relatif } \\
(\mathbf{\% )}\end{array}$ & Kriteria & $\begin{array}{c}\text { Jumlah } \\
\text { Kriteria }\end{array}$ \\
\hline$\leq 4,75$ & 1 & 6,7 & Baik Sekali & 3 \\
$4,75-5,36$ & 2 & 13,3 & Baik & 3 \\
\hline $5,36-5,98$ & 8 & 53,3 & Sedang & \\
$5,98-6,59$ & 3 & 20 & Kurang & 12 \\
$\geq 6,59$ & 1 & 6,7 & Kurang Sekali & \\
\hline
\end{tabular}

Dengan demikian berdasarkan hasil analisis pada tabel 4 keseluruhan 12 orang (80\%) dari 15 orang hasil tes cenderung banyak berada di bawah rata-rata (dibawah kriteria baik).

\subsubsection{Hasil t- test}

Tujuan tes ini untuk mengetahui kelincahan bergerak dalam berlari secepat mungkin dengan melewati beberapa rintangan dalam satuan detik.

Tabel 5. Klasifikasi Hasil Unsur Kelincahan T-Test pada Peserta Kegiatan Ekstrakurikuler Bolabasket SMAN 1 Gondanglegi Kabupaten Malang Kelompok Putra

\begin{tabular}{ccccc}
\hline Skor Interval & Frekuensi & Frekuensi Relatif (\%) & Kriteria & $\begin{array}{c}\text { Jumlah } \\
\text { Kriteria }\end{array}$ \\
\hline$\leq 11,00$ & 0 & 0 & Baik Sekali & 5 \\
$11,00-11,52$ & 5 & 33,3 & Baik & \\
\hline $11,52-12,03$ & 5 & 33,3 & Sedang & 10 \\
$12,03-12,55$ & 5 & 33,3 & Kurang & 10 \\
$\geq 12,55$ & 0 & 0 & Kurang Sekali & \\
\hline
\end{tabular}

Dengan demikian berdasarkan hasil analisis pada tabel 5 keseluruhan 10 orang $(66,7 \%)$ dari 30 orang hasil tes cenderung banyak berada di bawah rata-rata (dibawah kriteria baik).

Tabel 6. Klasifikasi Hasil T-Test Meter pada Peserta Kegiatan Ekstrakurikuler Bolabasket SMAN 1 Gondanglegi Kabupaten Malang Kelompok Putri

\begin{tabular}{ccccc}
\hline Skor Interval & Frekuensi & Frekuensi Relatif (\%) & Kriteria & $\begin{array}{c}\text { Jumlah } \\
\text { Kriteria }\end{array}$ \\
\hline$\leq 11,16$ & 1 & 6,7 & Baik Sekali & 3 \\
$11,16-12,53$ & 2 & 13,3 & Baik & \\
\hline $12,53-13,90$ & 11 & 73,3 & Sedang & \\
$13,90-15,27$ & 0 & 0 & Kurang & 12 \\
$\geq 15,27$ & 1 & 6,7 & Kurang Sekali & \\
\hline
\end{tabular}

Dengan demikian berdasarkan hasil analisis pada tabel 6 keseluruhan 12 orang (80\%) dari 15 orang hasil tes cenderung banyak berada di bawah rata-rata (dibawah kriteria baik). 


\subsubsection{Hasil tes chest pass throw}

Tujuan tes ini adalah untuk mengukur kekuatan otot lengan.

Tabel 7. Klasifikasi Hasil Unsur Daya Ledak (Otot Lengan) Chest Pass Throw Meter pada Peserta Kegiatan Ekstrakurikuler Bolabasket SMAN 1 Gondanglegi Kabupaten Malang Kelompok Putra

\begin{tabular}{ccccc}
\hline Skor Interval & Frekuensi & Frekuensi Relatif (\%) & Kriteria & $\begin{array}{c}\text { Jumlah } \\
\text { Kriteria }\end{array}$ \\
\hline$\geq 4,46$ & 1 & 6,7 & Baik Sekali & 3 \\
$3,99-4,46$ & 2 & 13,3 & Baik & \\
\hline $3,53-3,99$ & 8 & 53,3 & Sedang & 12 \\
$3,06-3,53$ & 3 & 20 & Kurang & \\
$\geq 3,06$ & 1 & 6,7 & Kurang Sekali & \\
\hline
\end{tabular}

Dengan demikian berdasarkan hasil analisis pada tabel 7 keseluruhan 12 orang (80\%) dari 15 orang hasil tes cenderung banyak berada di bawah rata-rata (dibawah kriteria baik).

Tabel 8. Klasifikasi Hasil Unsur Daya Ledak (Otot Lengan) Chest Pass Throw Meter pada Peserta Kegiatan Ekstrakurikuler Bolabasket SMAN 1 Gondanglegi Kabupaten Malang Kelompok Putri

\begin{tabular}{ccccc}
\hline Skor Interval & Frekuensi & Frekuensi Relatif (\%) & Kriteria & $\begin{array}{c}\text { Jumlah } \\
\text { Kriteria }\end{array}$ \\
\hline$\geq 4,08$ & 1 & 6,7 & Baik Sekali & 5 \\
$3,65-4,08$ & 4 & 26,7 & Baik & \\
\hline $3,22-3,65$ & 5 & 33,3 & Sedang & \\
$2,79-3,22$ & 5 & 33,3 & Kurang & 10 \\
$\leq 2,79$ & 0 & 0 & Kurang Sekali & \\
\hline
\end{tabular}

Dengan demikian berdasarkan hasil analisis pada tabel 8 keseluruhan 10 orang $(66,7 \%)$ dari 15 orang hasil tes cenderung banyak berada di bawah rata-rata (dibawah kriteria baik).

\subsubsection{Hasil tes vertical jump}

Tujuan tes ini adalah untuk mengukur kekuatan otot tungkai.

Tabel 9. Klasifikasi Hasil Unsur Daya Ledak (Otot Tungkai) Vertical Jump Meter pada Peserta Kegiatan Ekstrakurikuler Bolabasket SMAN 1 Gondanglegi Kabupaten Malang Kelompok Putra

\begin{tabular}{ccccc}
\hline Skor Interval & Frekuensi & Frekuensi Relatif (\%) & Kriteria & $\begin{array}{c}\text { Jumlah } \\
\text { Kriteria }\end{array}$ \\
\hline$\geq 288$ & 1 & 6,7 & Baik Sekali & 5 \\
$279-288$ & 4 & 26,7 & Baik & \\
\hline $270-279$ & 5 & 33,3 & Sedang & \\
$261-270$ & 4 & 26,7 & Kurang & 10 \\
$\leq 261$ & 1 & 6,7 & Kurang Sekali & \\
\hline
\end{tabular}


Dengan demikian berdasarkan hasil analisis pada tabel 9 keseluruhan 10 orang (70\%) dari 30 orang hasil tes cenderung banyak berada di bawah rata-rata (dibawah kriteria baik).

Tabel 10. Klasifikasi Hasil Unsur Daya Ledak (Otot Tungkai) Vertical Jump Meter pada Peserta Kegiatan Ekstrakurikuler Bolabasket SMAN 1 Gondanglegi Kabupaten Malang Kelompok Putri

\begin{tabular}{ccccc}
\hline Skor Interval & Frekuensi & Frekuensi Relatif (\%) & Kriteria & $\begin{array}{c}\text { Jumlah } \\
\text { Kriteria }\end{array}$ \\
\hline$\geq 260$ & 1 & 6,7 & Baik Sekali & 7 \\
$250-260$ & 6 & 40 & Baik & \\
\hline $240-250$ & 4 & 26,7 & Sedang & \\
$230-240$ & 3 & 20 & Kurang & 8 \\
$\leq 230$ & 1 & 6,7 & Kurang Sekali & \\
\hline
\end{tabular}

Dengan demikian berdasarkan hasil analisis pada tabel 4.17 keseluruhan 8 orang $(53,3 \%)$ dari 15 orang hasil tes cenderung banyak berada di bawah rata-rata (dibawah kriteria baik).

\subsection{Pembahasan}

\subsubsection{Kecepatan}

Secara keseluruhan dari hasil analisis unsur kecepatan berupa tes lari 30 meter pada kelompok putra yang termasuk pada kriteria baik sampai baik sekali yaitu terdapat 3 orang (20\%) dari 15 orang, sedangkan yang berada di bawah sedang sampai kurang sekali berjumlah 12 orang (80\%) dari 15 orang. Pada kelompok putri yang termasuk pada kriteria baik sampai baik sekali yaitu terdapat 3 orang (20\%) dari 15 orang, sedangkan yang berada di bawah sedang sampai kurang sekali berjumlah 12 orang $(80 \%)$ dari 15 orang. Hasil analisis menunjukkan bahwa kondisi fisik unsur kecepatan berada di rentang sedang sampai dengan kurang sekali padahal unsur kondisi kecepatan sangat diperlukan dalam permainan bolabasket dan ini sesuai dengan pendapat Lee (2010) seorang pemain bolabasket membutuhkan kecepatan dan unsur sangat penting untuk ditingkatkan.

Dari hasil analisa lapangan peneliti menemukan penyebab kurangnya hasil kemampuan kondisi fisik dari unsur kecepatan disebabkan oleh latihan yang tidak rutin dan program latihan tidak diterapkan secara benar. Seperti yang diungkapkan oleh bapak Oki selaku pelatih bahwa latihan hanya dilakukan sekali dalam seminggu dan diadakan setiap jumat sore. Sehingga dapat disimpulkan bahwa latihan tidak dilakukan dengan rutin sehingga menghambat perkembangan pemain. Hal ini sesuai dengan pendapat Sidik, Pesurnay \& Afari (2019) latihan olahraga diharuskan mulai dari usia muda sehingga tubuh dan pikiran bisa dikembangkan secara menyeluruh, terus-menerus dan sistematis. Hal ini harus dilakukan dengan perencanaan program yang baik, hati-hati, dan tidak hanya melakukan untuk jangka yang singkat (pendek). Menurut Rosadi (2018) Frekuensi latihan yang ideal dilakukan sebanyak 3-5 kali perminggu, berdasarkan pada prinsip latihan ada hari latihan berat dan ada hari latihan ringan. Intensitas menyatakan berat ringannya beban latihan dan merupakan faktor utama yang memengaruhi efek latihan terhadap fungsi tubuh atau fungsi dari kuatnya respons saraf terhadap beban tertentu pada waktu latihan. Type adalah bentuk latihan yang dilakukan dan durasi adalah lamanya waktu yang digunakan dalam latihan. Dapat disimpulkan 
bahwa latihan dalam seminggu bisa dilakukan lebih dari 2 kali berdasarkan program latihan yang telah disusun.

Kecepatan dapat dilatih menggunakan metode latihan interval. Volume latihan berupa lari cepat. Intensitas antara 40\%-60\% dari kemampuan maksimal, recovery antara 2-3 menit. Jumlah ulangan 50\% dari maksimum repetisi (Budiwanto 2012). Dalam permainan bolabasket unsur kecepatan dibutuhkan dalam aktivitas menggiring bola ke daerah lawan dan oleh karena itu pemain bolabasket harus memiliki kecepatan tinggi agar dapat melakukan suatu gerak gerakan yang singkat. Sesuai dengan pengertian menurut Fenanlampir (2015) kecepatan merupakan kemampuan bergerak seseorang dengan kecepatan tercepatnya.

Dalam penelitian yang pernah dilakukan oleh Supian (2014) tentang "Kontribusi Kecepatan Lari dan Kelincahan terhadap Kecepatan dribbling Bolabasket pada Pemain Basket Putra SMKN 3 Banjarbaru" berdasarkan hasil penelitian ada kontribusi kecepatan lari terhadap kecepatan dribbling bola basket pada pemain putra basket Putra SMKN 3 Banjarbaru dengan hasil kontribusi relatif $32,62 \%$ dan kontribusi efektif $61,40 \%$. Artinya kecepatan sangat dibutuhkan dalam permainan bolabasket misalnya dalam teknik seperti dribbling.

\subsubsection{Kelincahan}

Dari paparan hasil analisis unsur kelincahan berupa t- test pada kelompok putra yang termasuk pada kriteria baik sampai baik sekali yaitu terdapat 5 orang $(33,3 \%)$ dari 15 orang, sedangkan yang berada di bawah sedang sampai kurang sekali berjumlah 10 orang $(66,7 \%)$ dari 15 orang. Untuk kelompok putri yang termasuk pada kriteria baik sampai baik sekali yaitu terdapat 3 orang (20\%) dari 15 orang, sedangkan yang berada di bawah sedang sampai kurang sekali berjumlah 12 orang (80\%) dari 15 orang.

Penyebab kondisi fisik khusus pada unsur kelincahan yang kurang juga dapat dikarenakan mengabaikan atau salah menafsirkan pada prinsip, yaitu prinsip spesialisasi. Hal ini sesuai dengan pendapat Sidik, Pesurnay \& Afari (2019) bahwa prinsip spesialisasi melatih kapasitas dan teknik yang dibutuhkan untuk aktivitas khusus atau nomor khusus. Maksudnya dalam permainan bolabasket pergerakan pemain yang melibatkan unsur kelincahan gerakan yang dilakukan tidak hanya bergerak maju ke depan langsung balik atau sebaliknya. Sedangkan dalam permainan bola basket pergerakan pemain yaitu maju ke depan, mundur, bergerak ke samping, kanan kiri atau ke depan balik ke belakang. melihat karakteristik gerakan kelincahan tersebut latihan kelincahan tersebut latihan kelincahan seharusnya menerapkan prinsip spesialisasi yaitu spesialisasi pada otot-otot yang terlibat aktif bergerak sesuai dengan ciri-ciri tersebut, jadi latihan harus melibatkan otot-otot khusus yang banyak terlibat dalam gerakangerakan tersebut.

Hal tersebut diperkuat dengan yang disampaikan oleh Ambarukmi, dkk (2007) menyatakan bahwa dalam prinsip-prinsip yang dibutuhkan dalam latihan yaitu: (1) partisipasi aktif artinya pelatih dan pemain harus bertanggung jawab terhadap pelaksanaan program latihan untuk menghasilkan prestasi yang tinggi, (2) perkembangan multilateral artinya tahap perkembangan multilateral diletakkan pada awal program pembinaan sebelum memasuki tahapan spesialisasi, (3) individual artinya setiap pemain memiliki potensi yang berbeda-beda, untuk itu pelatih perlu mempertimbangkan perbedaan individual berupa faktor keturunan, umur perkembangan, dan umur latihan, (4) overload artinya pemain perlu latihan beban lebih. 
Hasil beberapa komponen fisik yang belum menunjukkan keadaan baik disebabkan karena pelaksanaan latihan tidak ada latihan khusus atau peningkatan kondisi fisik. Selain itu menurut Harsono (2018) yang mengatakan bahwa dalam latihan tidak memanfaatkan polapola latihan atau macam-macam model latihan yang dibutuhkan dan sesuai dengan karakteristik dari komponen kondisi fisik khusus dalam olahraga bolabasket (mengembangkan pola-pola latihan). Kelincahan khusus adalah kelincahan untuk melakukan gerakan dalam cabang olahraga khusus, dimana cabang olahraga yang lain tidak dibutuhkan. Contoh: loncat indah, senam, bulutangkis dan bolabasket. Ciri-ciri latihan kelincahan antara lain : (1) bentuk latihan harus ada gerakan mengubah posisi dan arah badan dengan kecepatan tinggi, (2) rangsangan terhadap pusat syaraf sangat menentukkan keberhasilan latihan kelincahan, (3) adanya rintangan-rintangan untuk bergerak (Budiwanto 2012). Sidik, Pesurnay \& Afari (2019) berpendapat bahwa bentuk-bentuk latihan kelincahan dapat dilakukan seperti zig-zag, boomerang, shuttle run, Illinois, arrowhead agility, t-test, obstacle dan lain-lain.

Dalam penelitian yang pernah dilakukan oleh Fantiro dan Saputra (2015) tentang "Pengaruh Latihan Ladder Speed Run dan Shuttle Run terhadap Kecepatan dan Kelincahan" berdasarkan hasil penelitian bahwa latihan ledder speed run memberikan pengaruh lebih baik dari latihan shuttle run dan kelompok kontrol terhadap peningkatan kecepatan dan kelincahan.

Selain itu juga unsur kelincahan sangat penting digunakan dalam permainan bolabasket untuk melewati lawan, dan memperdaya lawan atau pada saat akan menyerang tapi dihadang oleh lawan, sesegera mungkin bergerak dan mengelak agar bola tidak direbut oleh lawan. Selaras dengan pengertian kelincahan yang dikemukakan oleh Widiastuti (2015) berpendapat bahwa kelincahan adalah kemampuan seseorang untuk mengubah arah atau posisi tubuh dengan cepat/singkat yang dilakukan bersama-sama dengan gerakan lainnya (dengan tepat).

\subsubsection{Daya Ledak (Otot lengan dan tungkai)}

Untuk hasil analisis unsur daya ledak otot lengan berupa tes chest pass throw pada kelompok putra yang termasuk pada kriteria baik sampai baik sekali yaitu terdapat 3 orang (20\%) dari 15 orang, sedangkan yang berada di bawah sedang sampai kurang sekali berjumlah 12 orang (80\%) dari 15 orang. Kelompok putri yang termasuk pada kriteria baik sampai baik sekali yaitu terdapat 5 orang (30\%) dari 15 orang, sedangkan yang berada di bawah sedang sampai kurang sekali berjumlah 10 orang $(70 \%)$ dari 15 orang.

Sedangkan untuk hasil analisis unsur daya ledak otot tungkai berupa tes vertical jump pada kelompok putra yang termasuk pada kriteria baik sampai baik sekali yaitu terdapat 5 orang (30\%) dari 15 orang, sedangkan yang berada di bawah sedang sampai kurang sekali berjumlah 10 orang (70\%) dari 15 orang. Untuk kelompok putri yang termasuk pada kriteria baik sampai baik sekali yaitu terdapat 7 orang $(46,7 \%)$ dari 15 orang, sedangkan yang berada di bawah sedang sampai kurang sekali berjumlah 8 orang $(53,3 \%)$ dari 15 orang.

Daya ledak otot tungkai memiliki peranan penting dalam melakukan tembakan bebas sebab dengan kontraksi pada otot-otot tungkai saat melakukan hentakan ke atas yang maksimal akan menghasilkan daya dorong dari bawah yang besar yang diperlukan saat melakukan tembakan bebas sehingga arah bola dapat membentuk sudut parabola dan memungkin bola kedalam ring. Berdasarkan hasil penelitian diatas unsur daya ledak otot 
lengan dan tungkai peserta kegiatan ekstrakurikuler kelompok putra maupun putri lebih dominan dikriteria sedang sampai dengan kurang sekali, hal ini disebabkan karena kurangnya latihan yang menggunakan beban sehingga peserta tidak memiliki kekuatan otot yang maksimal. Selaras dengan hal tersebut disampaikan oleh Suharjana (2007) menyatakan bahwa latihan beban adalah latihan yang dilakukan secara sistematis dengan menggunakan beban sebagai alat untuk menambah kekuatan otot guna memperbaiki kondisi fisik pemain, mencegah terjadinya cidera atau untuk tujuan kesehatan. Hal tersebut diperkuat oleh

Latihan beban berarti mengarah pada kekuatan otot lengan dan otot tungkai. Untuk menentukan berat beban latihan menunjukkan pada massa atau ukuran berat dari beban yang digunakan dalam mengembangkan kemampuan otot. Untuk menentukan set, repetisi dan recovery, sesuai dengan pendapat Suharjana (2007) menyatakan bahwa secara umum cara terbaik membangun kekuatan adalah dengan mengangkat beban tiga set, yang terdiri dari 812 kali untuk setiap set. Latihan 5 set dengan 6 repetisi membangun kekuatan lebih cepat dibandingkan dengan 3 set dengan 6 repetisi. Interval istirahat antara 2-5 menit.

Dalam penelitian yang pernah dilakukan oleh Nurrochmah (2015) tentang "Efektivitas Pelatihan Beban Dinamis dan Statis untuk Meningkatkan Kekuatan dan Daya Eksplosif Otot Tungkai Dan Lengan" menyimpulkan bahwa pelatihan beban dinamis dan statis meningkatkan variabel kekuatan dan daya eksplosif otot secara signifikan. Pelatihan diagonal step lebih efektif meningkatkan kekuatan otot tungkai dan lengan. Pelatihan lateral hop lebih efektif meningkat daya eksplosif otot tungkai dan lengan. Pelatihan leg press cepat dan lambat efektif meningkatkan kekuatan dan daya eksplosif otot tungkai. Dan penelitian lainnya yang pernah dilakukan oleh Rusyda, Nurrochmah dan Heynoek (2016) tentang "Pengaruh Latihan Lempar Bolabasket terhadap Daya Ledak Otot Lengan" menyatakan latihan lempar bola basket pull chest pass lebih baik dalam meningkatkan kemampuan daya ledak otot lengan dibandingkan latihan lempar bolabasket duduk dilantai bersandar di tembok $(\alpha=0,05)$. Artinya latihan pull chest pass lebih efektif dalam meningkatkan daya ledak otot lengan.

Pemain membutuhkan daya ledak tungkai yang baik pada saat melakukan shooting, agar pada saat melakukan tembakan, musuh kesulitan untuk menghalangi pemain tersebut melakukan tembakan ke arah ring. Selain daya ledak tungkai, daya ledak lengan juga sangat diperlukan dalam permainan bolabasket agar dalam memasukan bola, pemain memiliki kekuatan untuk melemparkan bola sehingga dapat masuk ke dalam ring dengan cepat dan tepat. Annuri (2014). Artinya daya ledak otot tungkai dan lengan sangat mempengaruhi shooting dalam bolabasket.

Unsur daya ledak otot lengan dalam permainan bolabasket bisa digunakan pemain dalam mengoper ke sesama tim seperti chest pass, dan unsur daya ledak otot tungkai dibutuhkan untuk memasukan bola ke arah ring lawan sambil melompat. Untuk meningkatkan daya ledak memerlukan latihan kekuatan khususnya pada otot tubuh bagian atas dan tubuh bagian bawah agar dapat mengarahkan kekuatan otot dengan maksimal. Sebanding dengan pendapat Abduljabar \& Lubay (2015) berpendapat bahwa daya ledak adalah kemampuan otot atau sekelompok otot seseorang kekuatan maksimal yang dikerahkan dalam waktu yang sesingkat-singkatnya.

\section{Simpulan}

Berdasarkan penelitian yang dilakukan pada peserta kegiatan ekstrakurikuler bolabasket SMAN 1 Gondanglegi Kabupaten Malang yang diperoleh hasil tes kemampuan 
kondisi fisik peserta kegiatan ekstrakurikuler maka, penelitian ini dapat disimpulkan bahwa: 1). Unsur kecepatan pada kelompok putra termasuk kategori "sedang", dan kelompok putri termasuk kategori "sedang" pada SMAN 1 Gondanglegi Kabupaten Malang. 2). Unsur kelincahan pada kelompok putra termasuk kategori "sedang", dan kelompok putri termasuk kategori "sedang" pada SMAN 1 Gondanglegi Kabupaten Malang. 3) Unsur daya ledak (otot lengan) pada kelompok putra termasuk kategori "sedang", dan kelompok putri termasuk kategori "sedang"pada SMAN 1 Gondanglegi Kabupaten Malang. 3) Unsur daya ledak (otot tungkai) pada kelompok putra termasuk kategori "sedang", dan kelompok putri termasuk kategori "baik" pada SMAN 1 Gondanglegi Kabupaten Malang.

\section{Daftar Rujukan}

Abduljabar, B. \& Lubay, L. M. (2015). Pendidikan Jasmani, Olahraga, dan Kesehatan: Buku Guru. Jakarta: Kementrian Pendidikan dan Kebudayaan

Ambarukmi, D. W. (2007). Pelatihan Pelatih Fisik Level 1. Jakarta: Asdep Pengembangan Tenaga dan Pembimbaan Keolahragaan Deputi Bidang Peningkatan Prestasi dan IPTEK Olahraga Kementerian Negara Pemuda dan Olahraga

Ambler, V. (2016). Petunjuk untuk Pelatih dan Pemain Bola Basket. Bandung: Pionir Jaya

Amiq, F. (2016). Sepakbola (Sejarah Perkembangan, Teknik Dasar, Persiapan Kondisi Fisik, Peraturan Permaianan, dan Strategi Bermain). Malang: UM Press

Annuri, U. (2014). Hubungan Daya Ledak Otot Tungkai dan Otot Lengan dengan Kemampuan Shooting Atlet Bola Basket. Skripsi tidak diterbitkan. Yogyakarta: Fakultas Ilmu Keolahragaan Universitas Negeri Yogyakarta

Budiwanto, S. (2012). Metodologi Latihan Olahraga. Malang: FIK UM

Fantiro, F. A. \& Saputra, S. P. (2015). Pengaruh Latihan Ladder Speed Run dan Shuttle Run terhadap Kecepatan dan Kelincahan. Jurnal Iptek Olahraga, 17(3)

Fenanlampir, A., \& Faruq, M. M. (2015). Tes dan pengukuran dalam olahraga. Penerbit Andi.

Giriwijoyo, S. (2005). Manusia dan Olahraga. Bandung: ITB

Husdarta, J. S. (2011). Manajemen Pendidikan Jasmani. Bandung: Alfabeta

Kompri. (2015). Manajemen Pendidikan. Yogyakarta: Ar-Ruzz Media

Lee, B. (2003). Jump Rope Training. United States of America: Human Kinetics

Lubis, J. (2013). Panduan Praktis Penyusunan Program Latihan. Jakarta: PT Rajagrafindo Persada

Mu'arifin. (2009). Dasar-dasar Pendidikan Jasmani dan Olahraga. Malang: Univeristas Negeri Malang (UM PRESS)

Muhajir. (2014). Pendidikan Jasmani, Olahraga, dan Kesehatan. Bandung: Penerbit Erlangga

Nurrochmah, S. (2015). Efektivitas Pelatihan Beban Dinamis dan Statis untuk Meningkatkan Kekuatan dan Daya Eksplosif Otot Tungkai dan Lengan. Jurnal Iptek Olahraga, 17(3)

Nurrochmah, S. (2016). Tes dan Pengukuran dalam pendidikan Jasmani dan Keolahragaan. Malang: Universitas Negeri Malang

Prihatin, E. (2011). Manajemen Peserta Didik. Bandung: Alfabeta

Purwadi. (2014). Modul 1 Pengembangan Konsep Pendidikan Jasmani dan Olahraga. Surabaya: Univeritas Terbuka

Rahayu, T. (2017). Modul Penataran Pelatih Olahraga (Tingkat Muda). Jakarta: KONI Pusat Bidang Pendidikan dan Penataran

Roji \& Yulianti, E. (2014). Pendidikan Jasmani, Olahraga, dan Kesehatan. Jakarta: Kementerian Pendidikan dan Kebudayaan

Rosadi. (2018). Pengembangan Media Video Latihan Olahraga Kesehatan Bagi Masyarakat Umum Berbasis Web. Jurnal Terapan Ilmu Keolahragaan, 3(1), 40-46 
Rusyda, D. M, Nurrochmah, S. \& Heynoek, F. B. 2016. Perbedaan Pengaruh Latihan Lempar Bolabasket terhadap Peningkatan Kemampuan Daya Ledak Otot Lengan. Jurnal Pendidikan Jasmani, 26(2), 318-331

Sidik, D. Z, Pesurnay, P. L, \& Afari, L. (2019). Pelatihan Kondisi Fisik. Bandung: PT Remaja Rosdakarya

Sopiatin, P. (2010). Manajemen Belajar Berbasis Kepuasam Siswa. Bogor: Ghalia Indonesia

Suharjana. (2007). Latihan Beban: Sebuah Metode Latihan Kekuatan. Mediakora, 3(1), 80-101

Sumaryoto \& Nopembri, S. (2017). Pendidikan Jasmani, Olaharaga, dan Kesehatan. Jakarta: Kementerian Pendidikan dan Kebudayaan

Supian, A. 2014. Kontribusi Kecepatan Lari dan Kelincahan terhadap Kecepatan Dribbling Bolabasket paa Basket Putra SMKN 3 Banjarbaru. Jurnal Multilateral, 13(1), 37-52

Utama, A. M. B. (2011). Pembentukan Karakter Anak Melalui Aktivitas Bermain dalam Pendidikan Jasmani. Jurnal Pendidikan Jasmani Indonesial, 6(1,) 1-9

Wiarto, G. (2013). Fisiologi dan Olahraga. Yogyakarta: Graha Ilmu

Wiarto, G. (2015). Olahraga: Dalam Perspektif Sosial, Politik, Ekonomi, IPTEK dan Hiburan. Yogyakarta: Graha Ilmu

Widiastuti. (2015). Tes dan Pengukuran Olahraga. Depok: PT. Rajagrafindo Persada

Wiradihardja, S. \& Syarifudin. (2017). Pendidikan Jasmani, Olahraga, dan Kesehatan. Jakarta: Kementerian Pendidikan dan Kebudayaan

Yudiana, Y. (2012). Latihan Fisik. Bandung: FPOK-UPI Bandung 